самооценки стало 7 детей. Если сопоставить результаты нашей первичной диагностики детей с адекватной самооценкой было 6 детей. То после проведения промежуточного исследования стало 12 детей.

Таким образом, мы считаем, что разработанная нами психолого-педагогическая программа «Поверь в себя», позволяет сделать вывод о положительной динамике формирования адекватной самооценки младших школьников средствами арттерапии.

Список литературы:

1. Елисеев О.П. Практикум по психологии личности. - М.: Эксмо, 2009. - 578 с.

2. Лебедева Л.Д. Практика арт-терапии: подходы, диагностика, система занятий. СПб.: Речь, 2003. - 539 с.

3. Реан А.А. Психология человека от рождения до смерти. - М.: Просвещение, 2002. $-428 \mathrm{c}$.

\title{
Мотивация в учебной деятельности студентов
}

\section{Былахиров К.М., Ковтун Т.Ю., Северо-Восточный федеральный университет,} Якутск

Изменения, происходящие в новом тысячелетии во многих сферах деятельности человека, выдвигают новые требования к организации и качеству образования. Современный выпускник колледжа должен не только владеть специальными знаниями, умениями и навыками, но и ощущать потребность в достижениях и успехе. Необходимо прививать ему интерес к накоплению знаний, непрерывному самообразованию, поскольку постоянно развивающаяся система профессионального образования требует соответствия содержания, форм и методов обучения современным стандартам подготовки квалифицированного специалиста. В связи с этими изменениями проблема профессиональной мотивации приобретает сегодня особое значение [2].

Студент - это не школьник, которому можно сказать «так надо», студенту необходимо объяснить каким образом знания ему пригодятся в будущем. И если преподаватель отвечает в духе «в жизни пригодится», то обучающийся теряет интерес. Студент приходит в профессиональное учебное заведение не только за знаниями, а и за тем (в большей степени), чтобы стать хорошим специалистом в своей области. Поэтому преподаватель обязан уметь доказать студентам, что его предмет действительно будет полезен в их будущей деятельности.

Для того, чтобы выявить на сколько студенты автодорожного факультета заинтересованы в учебном процессе, мы провели исследования. Использовали методику Реана А.А., Якунина В.А. «Методика диагностики учебной мотивации» [1]. Исследования показали, что при обучении студентов направленность на внешние виды мотиваторов, такие как учет посещаемости, предстоящий экзамен, требования учебной дисциплины не приводит к поддержанию необходимого уровня мотивации. Однако, многие проблемы, связанные с поддержанием учебной мотивации у студентов, и созданием благоприятных условий для их обучения еще не достаточно изучены. В частности это связанно с постоянными реформами в системе образования. 
На 1 курсе особо выделяются мотивы учебной деятельности студентов. Поэтому целью нашего исследования было изучение мотивов к учебной деятельности с 1-го курса автодорожного факультета. Анкетируемым студентам предлагалось оценить мотивы своей учебной деятельности по пятибалльной шкале.

Итак, проанализировав результаты анкетирования мы выделили следующие особенности:

Из всего выше исследованного можно сделать вывод, что студенты 1-х курсов все одинаково мотивированы на творческую самореализацию это может объяснятся стремлением студентов к самореализации, творческому поиску, желанием участвовать в различных внеурочных мероприятиях. Вместе с тем выделяются и качественные различия в преобладании таких мотивов как коммуникативные, что вероятно связанно с процессом становления коллектива и межличностных отношений в нем; мотивы престижа; профессиональные - это может объясняться недостаточной сформированностью педагогической позиции и видения себя в педагогической профессии; учебно-познавательные что, как мы предполагаем связано с недостаточной познавательной активностью; социальные мотивы объясняется низким уровнем личной ответственности. Мотив избегания неудачи не актуален для студентов первокурсников.

В заключение можно добавить, что у студентов в большинстве своем характерны группоцентрические мотивы, то есть коллективное сознание преобладает над индивидуальным. Что составляет существенное различие с результатами анкетирования студентов университетов.

Можно предположить, что это связано с их личностной несориентированностью, а также с тем, что среди студентов нашего автодорожного факультета преобладают парни, последние более зависимы от социальной оценки.

\section{Список литературы:}

1. Бакшаева Н.А., Вербицкий А.А. Психология мотивации студентов: Учебное пособие/ Н.А.Бакшаева. - М.: Логос, 2006.- 184c.

2. Григорьева М.Н., Ковтун Т.Ю. Повышение мотивации учеников 5 и 9 классов при изучении иностранного языка путем использование новых информационных технологий. В сборнике: Актуальные проблемы развития личности в онтогенезе материалы IV Всероссийской научно-практической конференции. Чебоксары, 2015. 249c. 